\title{
Петрохимия неоархейских кислых метавулканитов лебяжинской свиты Кейвского террейна, арктическая зона Фенноскандинавского щита
}

\section{Балаганский В.В.}

Геологический институт Кольского научного ичентра PAH, Anamumbl, balagan@geoksc.apatity.ru

\begin{abstract}
Аннотация. С использованием вариационных диаграмм и метода главных компонент факторного анализа проведено сравнение химических составов лебяжинских кислых метавулканитов (ЛКВ) самой верхней части разреза лебяжинской свиты с возрастом $2678 \pm 7$ млн. лет с таковыми наиболее репрезентативной опубликованной выборки (РВ) этих метавулканитов. Все изученные ЛКВ образуют единый ряд от меланократовых до лейкократовых пород, в котором с увеличением содержаний $\mathrm{SiO}_{2}$ и $\mathrm{K}_{2} \mathrm{O}$ уменьшаются количества остальных главных элементов. Нагрузку фактора $\mathrm{F} 1$ определяют $\mathrm{SiO}_{2}$ и $\mathrm{K}_{2} \mathrm{O}$ (коэффициенты корреляции, $\mathrm{K}_{\mathrm{K}}, 0.94$ и 0.60 соответственно), фактора $\mathrm{F} 2-\mathrm{Na}_{2} \mathrm{O}$ и $\mathrm{Al}_{2} \mathrm{O}_{3}\left(\mathrm{~K}_{\mathrm{K}}=0.89\right.$ и 0.54), и фактора $\mathrm{F} 3-\mathrm{K}_{2} \mathrm{O}$ и $\mathrm{Al}_{2} \mathrm{O}_{3}\left(\mathrm{~K}_{\mathrm{K}}=0.67\right.$ и 0.50$)$. На диаграммах F1-F2 и F1-F3 поле мезократовых пород РВ разделяет поля лейко- и меланократовых пород РВ и не перекрывается с полем лейкократовых пород РВ. Это говорит об отсутствии единого петрохимического эталона для ЛКВ. Полученные результаты подтверждают корреляцию ЛКВ с кейвскими щелочными гранитами А-типа и их образование вместе с габбро-анортозитами в анорогенных условиях 2.68-2.66 млрд. лет назад.

Ключевые слова: кислые метавулканиты, петрохимия, А-гранитоиды, неоархей, Кейвский террейн, Кольский регион, Фенноскандинавский щит.
\end{abstract}

\section{Major element chemistry of Neoarchean acid metavolcanics of the Lebyazhka Formation, Keivy Terrane, Arctic part of the Fennoscandian Shield}

\section{Balagansky V.V.}

Geological Institute of the Kola Science Center of the Russian Academy of Sciences, Apatity balagan@geoksc.apatity.ru

\begin{abstract}
Major element contents in Lebyazhka acid metavolcanics (LAM) that compose the uppermost part of the Lebyazhka Formation and are dated at $2678 \pm 8$ Ma have been compared with those of the most representative LAM collection available in the literature (RLAM) using variation diagrams and principal component plots. All these LAM form a single series, in which contents of $\mathrm{SiO}_{2}$ and $\mathrm{K}_{2} \mathrm{O}$ rise as contents of other major elements decline. Loading of factor $\mathrm{F} 1$ is defined by $\mathrm{SiO}_{2}$ and $\mathrm{K}_{2} \mathrm{O}$ (correlation coefficients, $\mathrm{C}_{\mathrm{C}}, 0.94$ and 0.60 , respectively), factor 2 by $\mathrm{Na}_{2} \mathrm{O}$ and $\mathrm{Al}_{2} \mathrm{O}_{3}\left(\mathrm{C}_{\mathrm{C}}=0.89\right.$ and 0.54$)$, and factor 3 by $\mathrm{K}_{2} \mathrm{O}$ and $\mathrm{Al}_{2} \mathrm{O}_{3}\left(\mathrm{C}_{\mathrm{C}}=0.67\right.$ and 0.50$)$. On $\mathrm{F} 1-\mathrm{F} 2$ and $\mathrm{F} 1-\mathrm{F} 3$ plots all the LAM form a single series, in which the field of mesocratic RLAM separates those of leuco- and melanocratic RLAM and does not overlap with the field of leucocratic RLAM. It suggests that there is no single chemical composition standard suitable for the LAM. This study confirms that the LAM correlate with the Keivy A-type granites, and all these rocks and the Keivy gabbro-anorthosites formed in an anorogenic setting 2.68-2.66 Ga ago.

Key words: acid metavolcanics, major element chemistry, A-granitoid, Neoarchean, Keivy Terrane, Kola region, Fennoscandian Shield.

\section{Введение}

Кейвский террейн является составной частью архейской Кольской провинции, расположенной в северо-восточной части Фенноскандинавского щита (рис. 1 a), которая входит в арктическую зону России. Одной из отличительных черт Кейвского террейна (рис. 1 б) является парагенетическая ассоциация щелочных гранитов (Батиева, 1976) и габбро-анортозитов (Юдин, 1980) с возрастом 2.66-2.67 млрд. лет (Митрофанов и др., 2000; Баянова, 2004; Ветрин, Родионов, 2009; Кудряшов и др., 2019). Эта ассоциация сходна с комплексом анорогенных гранитов рапакиви и габбро-анортозитов палеопротерозоя (Радченко и др., 1992) и для ее неоархейских щелочных гранитов и габбро-анортозитов предполагаются генетическая связь и образование в анорогенных условиях (Zozulya et al., 2005; Zozulya, Eby, 2008, 2009). Другой отличительной чертой Кейвского террейна является широкое развитие архейских кислых метавулканитов, которые объединяются в ле-
\end{abstract}


(a)

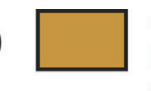

Фанерозой и рифрей-Phanerozoic \& Riphean

Архей и островодужный палеопротерозой-Archean \& arc-related Paleoproterozoic

Архей и рифтогенный палеопротерозой Archean \& rift-related Paleoproterozoic

ЛКО = Лапландско-Кольский ороген-LKO, Lapland-Kola orogen (2.0-1.9 млрд лет-Ga). Архейские провинции: БП = Беломорская, КП = Кольская Archean province: $B P=$ Belomorian, $K P=K o l a$

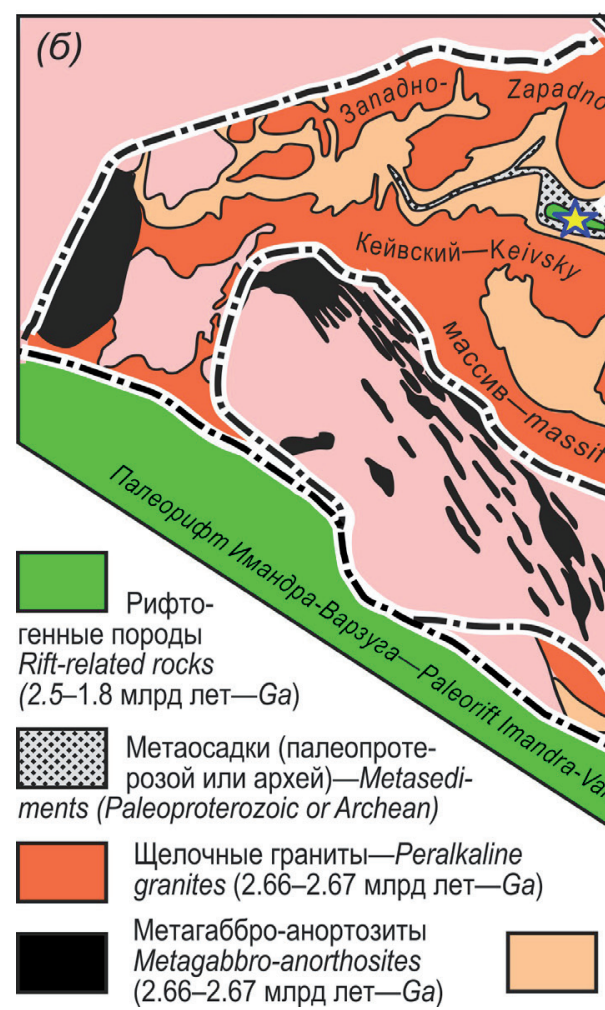

Островодужный палеопротерозой-Arc-related Paleoproterozoic
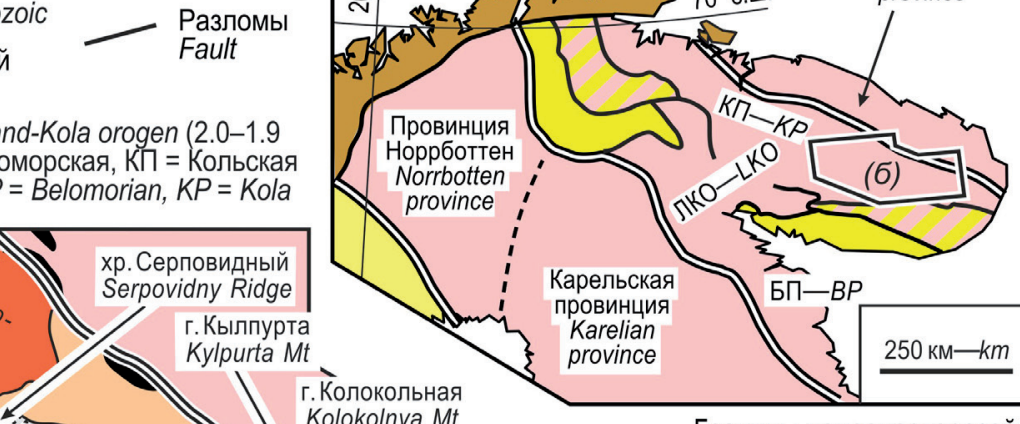

Колокольная

Границы палеопротерозойских орогенов-Boundary of Paleoproterozoic orogen

Рис. 1. (а) Главные тектонические единицы северной части Фенноскандинавского щита. (б) Схематическая геологическая карта Кейвского террейна (Геологическая карта..., 1996, с упрощениями).

Fig. 1. (a) Major tectonic units of the northern Fennoscandian Shield. (b) Schematic geological map of the Keivy terrane (Geological map..., 1996, simplified).

бяжинскую свиту (Белолипецкий и др., 1980; Минц, 2010) и вместе с гранитоидами фундамента являются вмещающими породами для щелочных гранитов и габбро-анортозитов (рис. 1 б). Возраст метавулканитов сначала был определен U-Pb методом по циркону из кислого метатуфа района возвышенности Малые Кейвы (рис. 1 б) и составил $2871 \pm 15$ млн. лет (возраст верхнего пересечения по пяти дискордантным точкам (Баянова, 2004)). Этот позднемезоархейский возраст и петрохимические данные по лебяжинским кислых метавулканитам играют значительную роль в тектонических сценариях начальных стадий архейского тектогенеза в Кольском регионе (Минц, 2010; Козлов и др., 2019). Полученные позднее U-Pb датировки по трем образцам метавулканитов из района гг. Кырпурта, Колокольная и Шуурурта (рис. 1 б) оказались почти на 200 млн. лет моложе, а наиболее обоснованная из них равна $2678 \pm 7$ млн. лет (возраст верхнего пересечения по восьми конкордантным и двум субконкордантным точкам (Balagansky et al., 2021)). Отсюда следует, что излияние лебяжинских метавулканитов произошло в том же возрастом интервале, что и внедрение анорогенных щелочных гранитов и габбро-анортозитов. Более того, согласно данным о петрогенных (главных), примесных и редкоземельных элементах, лебяжинские метавулканиты аналогичны щелочным гранитам и также интерпретируются как анорогенные породы (Balagansky et al., 2021). Taким образом, новые данные по возрасту, петрохимии и геохимии лебяжинских метавулканитов указывают на необходимость ревизии существующих моделей тектонического развития Кольского ре- 
гиона. Однако в работе (Balagansky et al., 2021) были проанализированы только те метавулканиты и щелочные граниты, для которых, помимо петрогенных элементов, имелись данные по примесным (второстепенным) и редкоземельным элементам. В результате в цитируемое исследование не была включена большая подборка силикатных химических анализов петрогенных элементов лебяжинских метавулканитов, опубликованных в работе (Белолипецкий и др., 1980), а также анализы двух образцов из коллекции М.В. Минца (Минц и др., 1996). Это обстоятельство несколько снижало обоснованность выводов, сделанных в работе (Balagansky et al., 2021). Настоящее сообщение устраняет этот пробел и посвящено сравнению данных по петрогенным элементам в образцах лебяжинских метавулканитов из коллекций разных исследователей, а также в щелочных гранитах, опубликованных в работах (Батиева, 1976; Белолипецкий и др., 1980; Balagansky et al., 2021). Сравнение проводилось с использованием вариационных диаграмм Харкера и одного из методов факторного анализа - метода главных компонент (Principal Component Analysis, Jolliffe, 2002). Для расчета главных компонент и сопутствующих параметров использовалась программа XLSTAT на базе компьютерной программы Excel

\section{Характеристика лебяжинских кислых метавулканитов и щелочных гранитов}

Кислые метавулканиты лебяжинской свиты архея, также известные как лебяжинские гнейсы, залегают на образованиях устьюгонькской свиты и перекрываются метаосадками Кейвского парасланцевого пояса (Белолипецкий и др., 1980). Устьюгонькская свита включает биотитовые гнейсы, часто с мусковитом и гранатом, двуслюдяные гнейсосланцы и плагиосланцы с прослоями амфиболовых, амфибол-биотитовых плагиосланцев и амфиболитов. В стратиграфической схеме кольского архея, разработанной в ГИ КНЦ РАН (Радченко и др., 1994), устьюгонькские образования отнесены к нижней части лебяжинской свиты. В результате лебяжинская свита является крупнейшим породным комплексом Кейвского террейна и занимает 40 \% его площади (рис. 1 б). Преобладающими типами пород верхней части этой свиты являются слабо рассланцованные мелкозернистые и реже среднезернистые биотитовые, мусковит-биотитовые и гранат-биотитовые гнейсы. Многие из них содержат реликты кварцевых, биотитовых и карбонатных миндалин и порфировых вкрапленников полевых шпатов; реже встречаются реликты пирокластических текстур, включая брекчиевидные разности с эксплозивными обломками и биотитовые обособления пламеневидной формы, характерные для игнимбритов. В составе верхней части свиты доминируют эффузивные разности, пирокластические породы занимают подчиненное положение. Метаосадки практически отсутствуют.

Степень метаморфизма лебяжинских кислых вулканитов отвечает среднетемпературной амфиболитовой фации, при этом они не были мигматизированы и на значительных площадях испытали щелочной метасоматоз. Главными индикаторами метасоматоза является появление в этих породах микроклина и гастингсита, и наиболее интенсивно метасоматоз проявился в породах нижних уровней лебяжинской свиты, а также в устьюгонькских образованиях (Белолипецкий и др., 1980). Новообразованные микроклиновые и гастингситовые гнейсы текстурно и структурно близки замещаемым лебяжинским гнейсам, связаны с ними постепенными переходами и отличаются только большей массивностью и большей однородностью (Белолипецкий и др., 1980; Минц, 2010). В наиболее метасоматизированных породах развитие гастингсита приводит к исчезновению граната и биотита, при этом местами появляется эгирин (Минц, 2010). Тем не менее, отмечается, что, согласно петрохимическим и геохимическим данным, метасоматоз не привел к существенному изменению химического состава метавулканитов, и микроклиновые и гастингситовые гнейсы в целом наследуют особенности состава этих пород (Минц, 2010).

Наблюдаемый структурный разрез кислых метавулканитов лебяжинской свиты в ее объеме, принятом в работе (Белолипецкий и др., 1980), интерпретируется как стратиграфический и подразделяется на верхнюю и нижнюю подсвиты. Нижняя подсвита сложена меланократовыми и мезократовыми биотитовыми гнейсами, содержащими все указанные выше признаки их первичной вулканической природы. Эти гнейсы для удобства дальнейшего анализа их петрохимических черт объединяются в две группы - группа I и группа II. В мезократовых разностях отмечаются редкие мало- 
мощные прослои лейкократовых гнейсов. Верхняя подсвита состоит из мезократовых и лейкократовых мусковит- и гранатсодержащих биотитовых гнейсов, которые, как и гнейсы нижней подсвиты, являются метавулканогенными породами. Они объединяются в группу III. Наиболее полный и представительный разрез верхней подсвиты обнажается в районе гор Шуурурта и Цыцнокура-Боллоурта к югу от залегающего на этой подсвите Кейвского парасланцевого пояса (рис. 1 б). Именно в этом районе Больших Кейв, ограниченном указанными горами и горами Кырпурта и Колокольная, были взяты 13 из 15 образцов из коллекций Т.А. Мысковой и В.В. Балаганского, химический состав которых приведен в работе (Balagansky et al., 2021). Таким образом, судя по положению в структурном разрезе, кислые метавулканиты, представленные этими 13 образцами, находятся в самой верхней части структурного разреза лебяжинской свиты, и их следует относить к образованиям ее верхней подсвиты. Из этой же части разреза в районе хр. Серповидный были взяты еще два образца из коллекции В.В. Балаганского. Наконец, все четыре образца лебяжинских метавулканитов, данные для которых опубликованы в монографии (Минц и др., 1996), были отобраны из гранат-биотитовых гнейсов, которые, согласно работе (Белолипецкий и др., 1980), встречаются только в верхней подсвите, то есть в верхней части разреза лебяжинской свиты. Все эти гнейсы объединяются в группу $I V$ (ниже для краткости $Г-I V)$. Эта верхняя часть разреза была наименее затронута щелочным метасоматозом и находится на значительном удалении от областей развития метасоматических микроклиновых и гастингситовых гнейсов, локализованных в центральных частях Кейвского террейна (Геологическая карта..., 1996; Белолипецкий и др., 1980),.

По петрохимическим данным и первичным структурам и текстурам, магматические протолиты лебяжинских гнейсов обеих подсвит отвечают дацитам, риодацитам, риолитам, трахитам, трахириолитам, трахириодацитам и туфам этих пород (Белолипецкий и др., 1980; Минц, 2010; Balagansky et al., 2021). Петрохимическая характеристика лебяжинских кислых вулканитов, данная в работе (Белолипецкий и др., 1980), основывается на химическом составе 48 образцов из коллекций геологов, изучавших геологию Кейвской возвышенности и прилегающих районов и картировавших эту территорию. Они включают 37 образцов, собранных геологами под руководством В.Г. Гаскельберга, два образца Е.Е. Федорова и один образец Б.А. Шлайфштейна, а также 11 образцов сотрудников Геологического института Кольского филиала АН СССР: Д.Д. Мирской (восемь образцов), И.Д. Батиевой, И.В. Белькова и Н.И. Плетневой (по одному образцу). Представляется, что эти образцы являются в полной мере представительными для верхних уровней разреза лебяжинской свиты, а группы $I, I I$ и $I I I$ в являются геологически репрезентативными и далее для краткости обозначаются как РГ-I, РГ-ІІ и РГ-ІІІІ.

Наиболее значимыми петрохимическими чертами лебяжинских пород являются большое содержание $\mathrm{K}_{2} \mathrm{O}$ и высокая железистость, причем железистость последовательно увеличивается вверх по разрезу от 0.78 у меланократовых биотитовых гнейсов до 0.96 у мусковит-биотитовых гнейсов соответственно в нижней и верхней частях свиты в понимании В.Г. Гаскельберга и его коллег (Белолипецкий и др., 1980). Вверх по разрезу также последовательно увеличивается содержание $\mathrm{SiO}_{2}$ и уменьшаются содержания всех остальных петрогенных элементов, за исключением $\mathrm{Na}_{2} \mathrm{O}$ и $\mathrm{K}_{2} \mathrm{O}$. Таким образом, кислые метавулканиты нижней части подсвиты петрохимически отличаются от таковых верхней подсвиты, что наглядно иллюстрирует компонентная диаграмма на рис. 14 в работе (Белолипецкий и др., 1980). На этой диаграмме указанные породы образуют два неперекрывающихся поля, между которыми, а между ними и внутри их располагаются фигуративные точки пород средней части разреза лебяжинской свиты. Все породы вместе образуют на диаграмме единую область, что предполагает их генетическую связь друг с другом.

Щелочные граниты являются самым распространенным типом плутонических пород Кейвского террейна и занимают $24 \%$ его площади (рис. 1 б). По результатам изучения всех массивов щелочных гранитов, И.Д. Батиева (1976) выделила девять петрографических разновидностей этих пород и привела для них средние содержания петрогенных элементов. В порядке увеличения количества в них $\mathrm{SiO}_{2}$ это следующие разновидности: (1) порфиритовые лепидомелан-гастингситовые, (2) гнейсовидные лепидомелан-гастингситовые, (3) энигматит-эгирин-арфведсонитовые, (4) эгирин- 
арфведсонитовые с энигматитом, (5) эгирин-арфведсонитовые, (6) магнетит-эгириновые, (7) лепидомелановые с феррогастингситом, (8) эгирин- и лепидомелановые с эгирином и арфведсонитом, (9) арфведсонит-эгириновые. Как и лебяжинские кислые метавулканиты, щелочные граниты отличаются высокой железистостью. По данным, опубликованным в работе (Balagansky et al., 2021), железистость в этих породах варьирует от 0.78 до 0.99, за исключением двух образцов из ЗападноКейвского массива с железистостью 0.57 и 0.72. При этом железистость, рассчитанная для средних химических составов крупнейших массивов щелочных гранитов - Западно-Кейвского и Понойского, а также всех девяти петрографических разновидностей этих пород, колеблется от 0.90 до 0.99.

\section{Петрохимия лебяжинских кислых метавулканитов и щелочных гранитов}

Анализ вариационных диаграмм. В работе (Balagansky et al., 2021) были приведены содержания петрогенных элементов для 17 образцов лейкократовых и мезократовых метавулканитов верхов лебяжинской свиты, который соответствует ее верхней подсвиты и, скорее всего, самой верхней части нижней подсвиты. Как уже отмечалось выше, 13 образцов были взяты в районе Больших Кейв, а два образца - в районе хр. Серповидного из метавулканитов рядом с северной и южной границами Кейвского парасланцевого пояса (рис. 1 б). Оставшиеся два образца были взяты из гранат-биотитовых гнейсов верхней части разреза свиты. С учетом соответствия перечисленных образцов кислых метавулканитов породам только верхних уровней лебяжинской свиты в понимании авторов работы (Белолипецкий и др., 1980), данные по подстилающим их устьюгонькским отложениям, относимых сейчас к лебяжинским породам, не рассматривались. В итоге в работе (Balagansky et al., 2021) были проанализированы средние составы рассматриваемых 17 образцов кислых метавулканитов лебяжинской свиты (группа $\Gamma-I V)$, трех групп верхних уровней ее разреза (РГ-I, РГ-II и РГ-ІІІ), Западно-Кейвского и Понойского щелочногранитных массивов, а также всех петрографических разновидностей щелочных гранитов. Согласно петрографическому описанию и положению в структурном разрезе метавулканиты Г-IV коррелируются с таковыми РГ- $I I$ и РГ-III.

На вариационных диаграммах содержания $\mathrm{TiO}_{2}, \mathrm{Al}_{2} \mathrm{O}_{3}$. $\mathrm{FeO} * \mathrm{MgO}, \mathrm{MnO}$ и $\mathrm{CaO}$ во всех рассматриваемых метавулканитах и щелочных гранитах обнаруживают обратную линейную зависимость от содержания $\mathrm{SiO}_{2}$ : они уменьшаются при возрастании доли кремнезема (рис. $2 a-e$ ). Фигуративные точки этих элементов образуют единый хорошо выраженный линейный тренд, кроме $\mathrm{MgO}$, фигуративных точки которого обнаруживают менее выдержанное линейное распределение. Исключение представляют только щелочи, которые проявляют разные тенденции: с увеличением количества $\mathrm{SiO}_{2}$ содержание $\mathrm{Na}_{2} \mathrm{O}$ снижается незначительно, меняясь в пределах всего лишь $1.3 \%$ (рис. 2 ж), тогда как доля $\mathrm{K}_{2} \mathrm{O}$ заметно возрастает (рис. 2 з).

Анализ компонентных диаграмм. Методом главных компонент были проанализированы данные для лебяжинских метавулканитов, опубликованные в работах (Белолипецкий и др., 1980; Balagansky et al., 2021), а также два анализа из монографии (Минц и др., 1996), не вошедшие в работу (Balagansky et al., 2021), в результате чего число анализов в группе Г- $I V$ составило 19. Анализ данных по петрогенным элементам щелочных гранитов всех массивов оказался невозможным из-за того, что в работе (Батиева, 1976), были опубликованы только средние составы разновидностей гранитов, а не первичные анализы образцов. Поэтом рассматривались только данные для 16 из 17 образцов Западно-Кейвского массива, приведенных в работе (Balagansky et al., 2021). Один анализ был исключен из-за аномально высоких содержаний $\mathrm{TiO}_{2}$ и $\mathrm{MnO}$ (1.28 и 1.08 мас. \% соответственно). Результаты анализа главных компонент представлены в таблицах 1 и 2, а также на рисунках 3 и 4.

Установлено, что все вариации химических составов лебяжинских кислых метавулканитов описываются девятью факторами. Нагрузка фактора F1, доля которого в общей структуре факторов равна $54.02 \%$ (табл. 1), определяется содержаниями $\mathrm{SiO}_{2}$ и в меньшей мере $\mathrm{K}_{2} \mathrm{O}$ (рис. 3 а) с коэффициентами корреляции $\left(\mathrm{K}_{\mathrm{K}}\right) 0.937$ и 0.599 соответственно (табл. 2). Для фактора F2 (его доля равна $17.64 \%$ ) определяющими являются $\mathrm{Na}_{2} \mathrm{O}$ и $\mathrm{Al}_{2} \mathrm{O}_{3}\left(\mathrm{~K}_{\mathrm{K}}=0.893\right.$ и 0.540). Эти два фактора занимают $71.66 \%$ от суммы всех факторов, что позволяют охарактеризовать главные петрохимические черты лебяжинских кислых лебяжинских кислых метавулканитов, достаточные для достижения цели данной работы. 

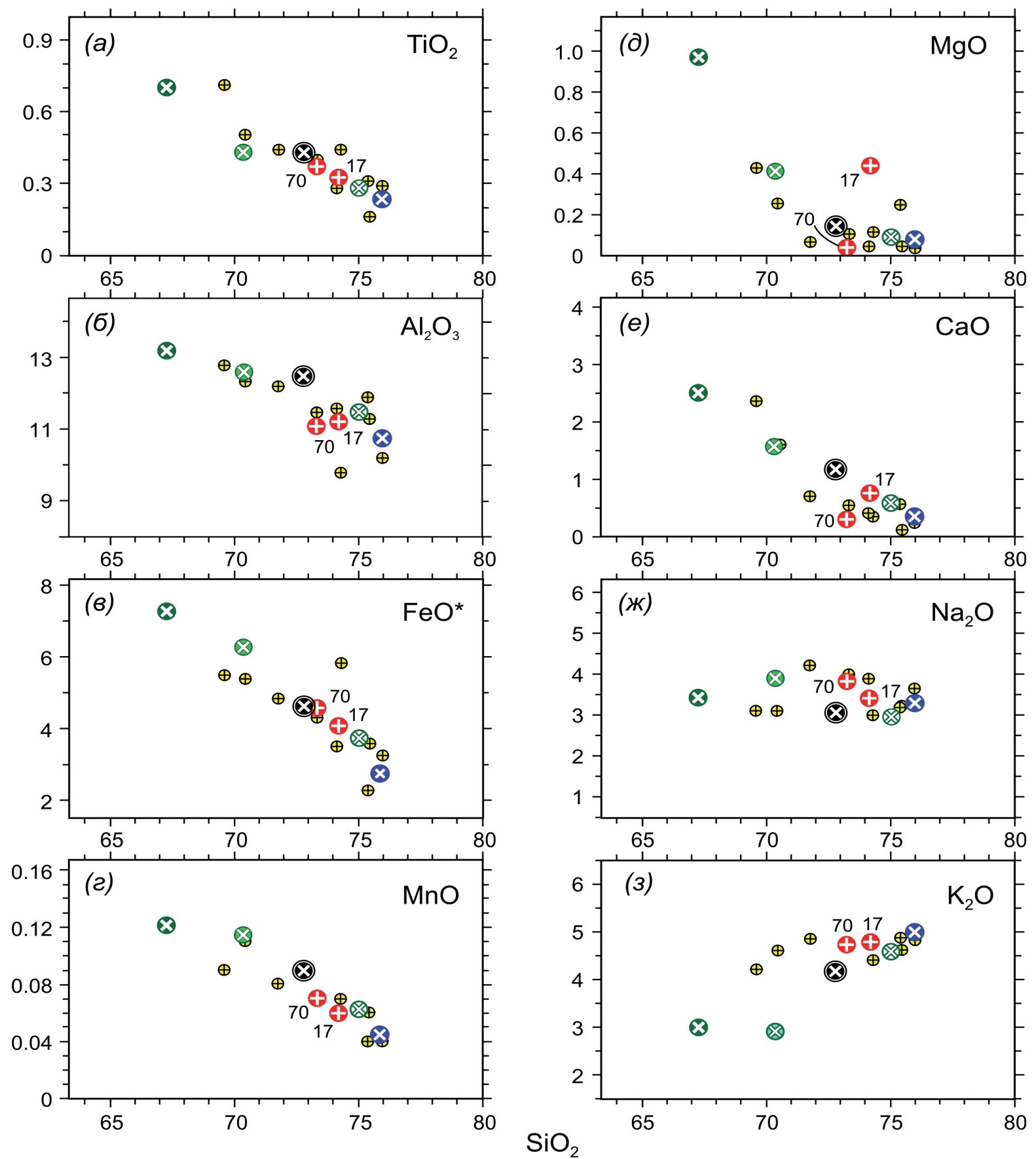

Средние составы гнейсов (кислых метавулканитов) лебяжинской свиты-Average composition of gneisses (acid metavolcanics) of the Lebyazhka Formation:

(ג) лейко- и мезократовых (группа Г-IV)-leuco- \& mesocratic (Group G-IV) ([1], N = 17),

лейко- и мезократовых верхней подсвиты (группа РГ-III)-leuco- \& mesocratic of the Upper Subformation (Group RG-III) $([2], N=10)$,

จ мезократовых нижней подсвиты (группа РГ-II)-mesocratic of the Lower Subformation (Group RG-II) ([2], N = 26),

м меланократовых нижней подсвиты (группа РГ-I)-melanocratic of the Lower Subformation (Group RG-I) ([2], N = 12).

Средние составы кейвских щелочных гранитов-Average composition of the Keivy peralkaline granites:

叉 Понойского массива-Ponoy massif ([3], N = 5),

$70 \oplus \oplus 17$ Западно-Кейвского массива-Zapadno-Keivsky massif ([4]), $N=70 ;[1], N=17)$,

$\oplus$ петрографических разновидностей во всех массивах - petrographical varieties in all the massifs [5].

References: 1 = Balagansky et al., 2021, 2 = Белолипецкий и др., 1980-Belolipetsky et al., 1980, 3 = Ветрин и др., 1999—Vetrin et al., 1999, 4 = Mikhailova et al., 2017, 5 = Батиева, 1976—Batiyeva, 1976.

Рис. 2. Вариационные диаграммы для лебяжинских кислых метавулканитов и щелочных гранитов.

Fig. 2. Variation diagrams for the Lebyazhka acid metavolcanics and peralkaline granites. 
Таблица 1. Параметры факторов.

Table 1. Eigenvalue, variability, and cumulative total.

\begin{tabular}{|l|c|c|c|c|c|c|c|c|c|}
\hline \multicolumn{1}{|r|}{ Факторы } & \multirow{2}{*}{ F1 } & F2 & F3 & F4 & F5 & F6 & F7 & F8 & F9 \\
\cline { 1 - 11 } Параметры & 4.86 & 1.59 & 0.89 & 0.59 & 0.38 & 0.30 & 0.26 & 0.12 & 0.02 \\
\hline Значение фактора & 54.02 & 17.64 & 9.91 & 6.54 & 4.22 & 3.25 & 2.93 & 1.28 & 0.22 \\
\hline Доля фактора, \% & 54.02 & 71.66 & 81.57 & 88.10 & 92.32 & 95.57 & 98.50 & 99.78 & 100.00 \\
\hline
\end{tabular}

Таблица 2. Корреляция между содержаниями оксидов и наиболее значимыми факторами.

Table 2. Correlations between oxide abundances and the most significant factors

\begin{tabular}{|c|c|c|c|c|c|}
\cline { 1 - 4 } Факторы & \multirow{2}{*}{$\mathrm{F} 1$} & $\mathrm{~F} 2$ & $\mathrm{~F} 3$ & $\mathrm{~F} 4$ & $\mathrm{~F} 5$ \\
\cline { 1 - 5 } $\mathbf{S i O}_{\mathbf{2}}$ & $\mathbf{0 . 9 3 7}$ & -0.052 & -0.284 & 0.053 & 0.022 \\
\hline $\mathrm{TiO}_{2}$ & -0.783 & -0.313 & 0.008 & -0.183 & -0.403 \\
\hline $\mathbf{A l}_{2} \mathbf{O}_{\mathbf{3}}$ & -0.572 & $\mathbf{0 . 5 4 0}$ & $\mathbf{0 . 4 9 6}$ & -0.300 & 0.130 \\
\hline $\mathrm{FeO}$ & -0.863 & -0.206 & 0.023 & 0.214 & -0.089 \\
\hline $\mathrm{MnO}$ & -0.738 & -0.004 & 0.198 & $\mathbf{0 . 5 9 1}$ & 0.111 \\
\hline $\mathrm{MgO}$ & -0.776 & -0.402 & -0.157 & -0.145 & 0.022 \\
\hline $\mathrm{CaO}$ & -0.829 & -0.184 & -0.193 & -0.207 & 0.374 \\
\hline $\mathbf{N a}_{\mathbf{2}} \mathbf{O}$ & -0.324 & $\mathbf{0 . 8 9 3}$ & -0.122 & 0.050 & -0.192 \\
\hline $\mathbf{K}_{\mathbf{2}} \mathbf{O}$ & $\mathbf{0 . 5 9 9}$ & -0.398 & $\mathbf{0 . 6 7 0}$ & -0.020 & -0.044 \\
\hline
\end{tabular}

Примечание: жирным шрифтом выделены оксиды с коэффициентами корреляции $\geq 0.5$. Note: oxides with values $\geq 0.5$ are written in bold.

(a)

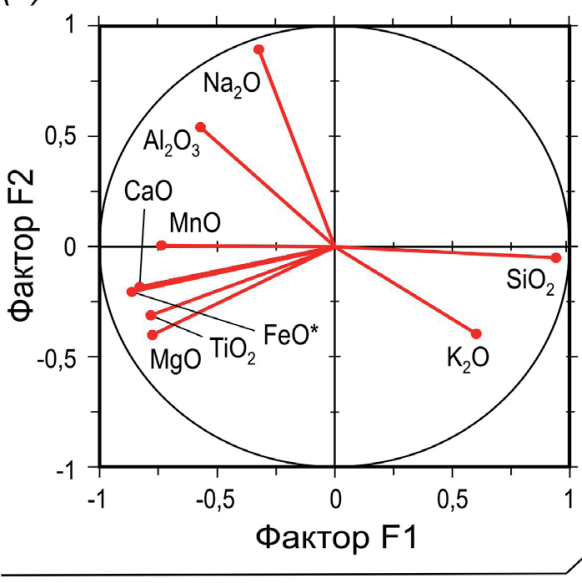

(б)

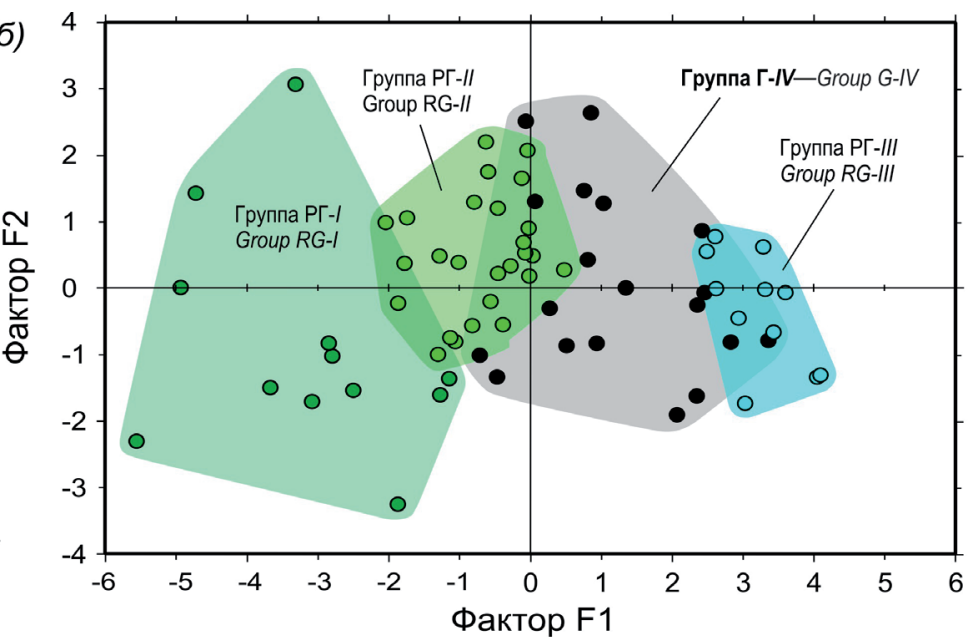

Лейко- и мезократовые гнейсы верхней части разреза-Leuco- \& mesocratic gneisses of the upper part of the geologic column (Balagansky et al., 2021). Гнейсы с разным положением в разрезе-Gneisses with different position in the geologic column (Белолипецкий и др., 1980-Belolipetsky et al., 1980): О лейко- и мезократовые верхней части разреза (верхней подсвиты)-leuco- \& mesocratic of the upper part of the geologic column (Upper Subformation) - мезократовые и—mesocratic and ○ меланократовые нижней части разреза (нижней подсвиты)-melanocratic of the lower part of the geologic column (Lower Subformation).

Рис. 3. Факторные диаграммы для оксидов петрогенных элементов лебяжинских кислых метавулканитов: (a) корреляция оксидов с факторами F1 и F2, (б) диаграмма F1-F2.

Fig. 3. Factor plots for oxides of major elements of Lebyazhka acid metavolcanics: (a) correlations between oxides and factors F1 and F2, (b) F1 vs F2 plot. 

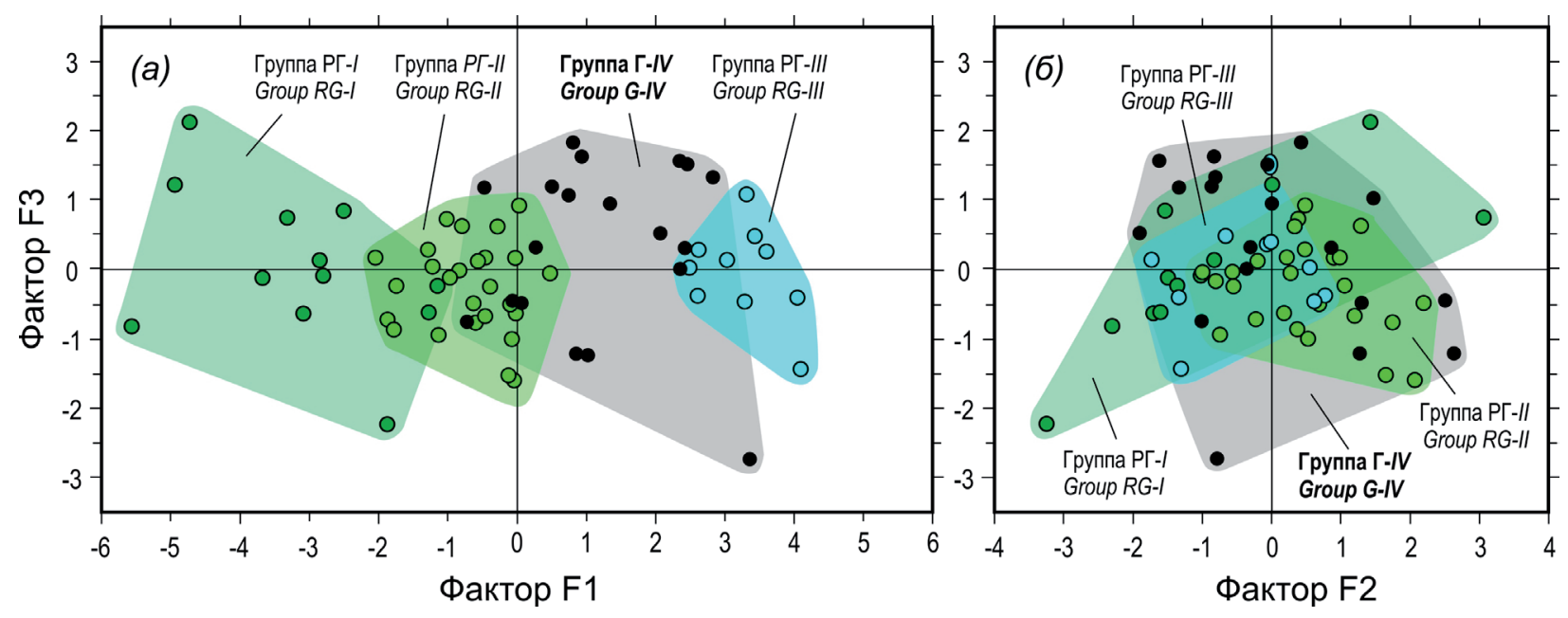

Рис. 4. Факторные диаграммы для оксидов петрогенных элементов лебяжинских кислых метавулканитов (условные обозначения те же, что и на рис. 3).

Fig. 4. Factor plots for major element oxides of Lebyazhka acid metavolcanics (for symbols see Fig. 3).

Анализ распределения фигуративных точек лебяжинских кислых метавулканитов на диаграмме F1-F2 (рис. 3 б) показывает, что увеличение фактора F1 отражает возрастание количества $\mathrm{SiO}_{2}$ и $\mathrm{K}_{2} \mathrm{O}$ и уменьшение количества всех остальных петрогенных элементов. Фигуративные точки групп РГ-II и РГ-III образуют две компактные области, удаленные друг от друга по оси F1 промежутком на ширину группы РГ- $I I I$. Фигуративные точки группы Г- $I V$ заполняют этот промежуток, их распределение по оси F2 почти не выходит за пределы областей групп РГ-II и РГ-III, а образованное ими поле перекрывается с этими областями. В то же время область фигуративных точек группы РГ-I более растянута по оси F2 и обнаруживает минимальное перекрытие с таковой группы РГ-ІІ. В результате фигуративные точки всех четырех групп образуют общее для них поле, вытянутое по оси F1.

Таким образом, в число важных петрохимических черт лебяжинских кислых метавулканитов следует включить поведение оксидов $\mathrm{SiO}_{2}, \mathrm{~K}_{2} \mathrm{O}, \mathrm{Na}_{2} \mathrm{O}$ и $\mathrm{Al}_{2} \mathrm{O}_{3}$, которые определяют нагрузку факторов $\mathrm{F} 1$ и F2. При этом оказывается, что $\mathrm{K}_{2} \mathrm{O}$ и $\mathrm{Al}_{2} \mathrm{O}_{3}$ определяют нагрузку следующего по значи-
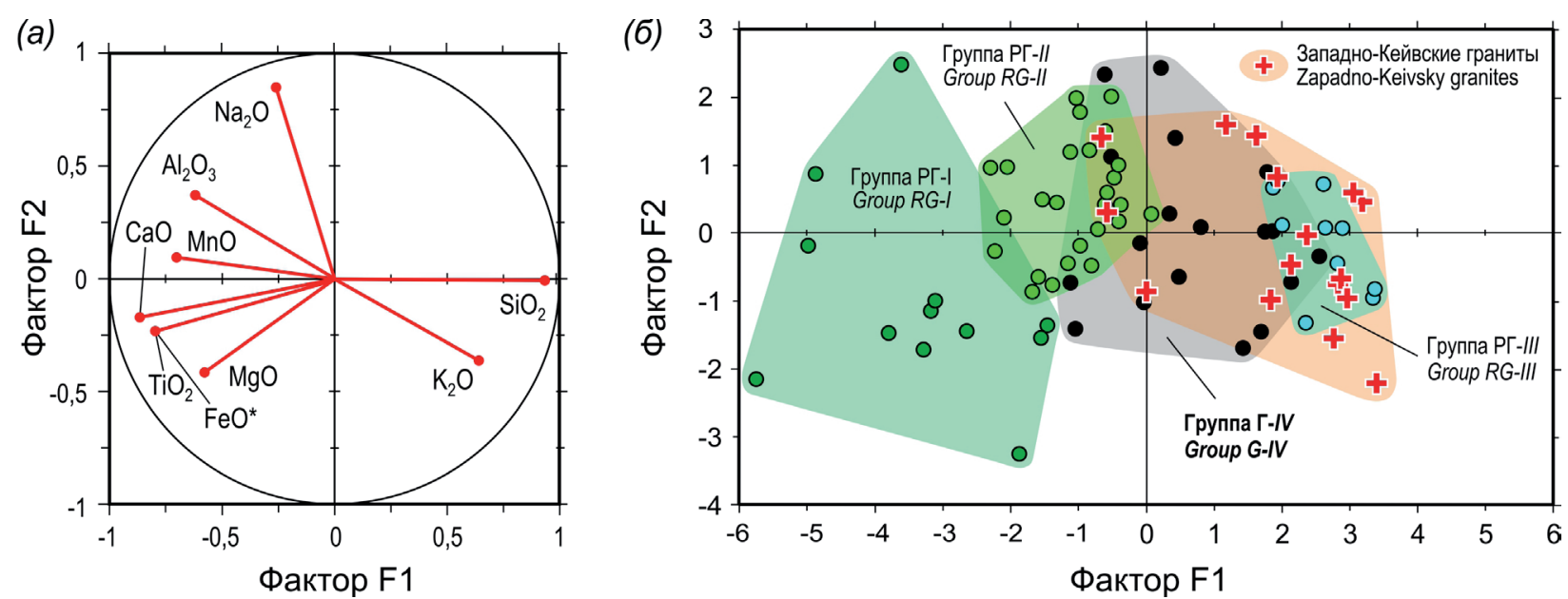

Рис. 5. Факторные диаграммы для оксидов петрогенных элементов лебяжинских кислых метавулканитов и западно-кейвских щелочных гранитов: (а) корреляция между оксидами и факторами F1 и F2, (б) диаграмма F1-F2 (условные обозначения те же, что и на рис. 3).

Fig. 5. Factor plots for oxides of major elements of Lebyazhka acid metavolcanics and peralkaline granites of the Zapadno-Keivsky massif: (a) correlations between oxides and factors F1 and F2, (b) F1 vs F2 plot (for symbols see Fig. 3). 
мости фактора F3, а суммарная доля факторов F1, F2 и F3 равна 81.57 \% (табл. 1). Хотя доля этого фактора составляет всего $9.91 \%$ и он уже может отражать статистический шум, для сравнения было проанализировано распределение фигуративных точек всех групп на диаграммах F1-F3 и F2-F3. На диаграмме F1-F3 (рис. 4 а) области фигуративных точек всех четырех групп метавулканитов обнаруживают последовательное и существенное перекрытие друг с другом. При этом области групп РГ- $I$ и $\Gamma-I V$ примыкают друг к другу по оси $\mathrm{F} 1$, а центр компактной области группы РГ-II совпадает с участком перекрытия. В целом на диаграмме F1-F3 наблюдается большее единство поля, общего для лебяжинских кислых метавулканитов. На диаграмме F2—F3 (рис. 4 б) все фигуративные точки рассматриваемых пород, за исключением трех точек группы РГ-I и одной точки группы $\Gamma-I V$, полностью перекрываются друг с другом и дают одно компактное поле.

Совместный анализ лебяжинских кислых метавулканитов и щелочных гранитов ЗападноКейвского массива показал принципиально такие же результаты. Сохраняются и характер корреляции между оксидами и факторами F1 и F2 (рис. 5 a), и единое для метавулканитов и вытянутое по оси F1 поле фигуративных точек, в правой части которого располагаются фигуративные точки гранитов (рис. 5 б). Доли факторов F1 и F 2 равны 50.84 и $14.58 \%$, а их сумма составляет $65.42 \%$ (для метавулканитов 54.02, 17.64 и $71.66 \%$ соответственно). Нагрузка фактора F1 определяется $\mathrm{SiO}_{2}$ и $\mathrm{K}_{2} \mathrm{O}$ при $\mathrm{K}_{\mathrm{K}}=0.94$ и 0.64 соответственно, а фактора $\mathrm{F} 2-\mathrm{Na}_{2} \mathrm{O}$ и $\mathrm{Al}_{2} \mathrm{O}_{3}$ при $\mathrm{K}_{\mathrm{K}}=0.85$ и 0.37 соответственно (для метавулканитов эти две пары К к равны 0.94-0.60 и 0.89-0.54 соответственно).

\section{Обсуждение результатов и выводы}

Главный вывод, который следует из проведенного анализа, состоит в том, что все рассмотренные группы лебяжинских кислых метавулканитов вместе со всеми петрографическими разновидностями и двумя крупнейшими массивами щелочных гранитов образуют на вариационных диаграммах общий тренд и единое, вытянутое по оси F1 поле на компонентных диаграммах. Для метавулканитов эти тренд и поле образуют последовательность РГ-I-РГ-II-Г-IV-РГ-III, отражающую уменьшение содержаний всех петрогенных элементов с увеличением количества $\mathrm{SiO}_{2}$ и в меньшей мере $\mathrm{K}_{2} \mathrm{O}$ от меланократовых разностей метавулканитов к лейкократовым. При этом область группы $\Gamma-I V$ заполняет на диаграммах $\mathrm{F} 1-\mathrm{F} 2$ и $\mathrm{F} 1-\mathrm{F} 3$ разрыв между областями групп РГ-II и РГ-III и перекрывается с ними (рис. 3 б и 4 б). В результате часть единого поля лебяжинских метавулканитов, образованная этими тремя областями, отличается бо́льшей плотностью фигуративных точек по сравнению с прилегающей к ней такой же по площади областью группы РГ- $I$ с минимальными содержаниями $\mathrm{SiO}_{2}$ и $\mathrm{K}_{2} \mathrm{O}$. Учитывая, что метавулканиты групп РГ-II, РГ- III и Г-IV петрографически соответствуют друг другу и находятся на одном и том же, самом верхнем уровне разреза лебяжинской свиты, полученные результаты указывают на то, что все эти метавулканиты генетически связаны друг с другом, а также с метавулканитыми группы РГ-I. Эта связь объясняется давно известным процессом кристаллизационной дифференциации магматических расплавов, когда последовательно образуются магмы все более кислого состава и происходит смена ранних меланократовых пород поздними лейкократовыми (например, Рябчиков, 1987). Для гранитных пород этот процесс всесторонне рассмотрен в монографии (Nédélec, Bouchez, 2015). Отсюда вытекает вывод о невозможности выделения единого для всей совокупности лебяжинских кислых метавулканитов петрохимического эталона, что наглядно иллюстрируют вариационные диаграммы Харкера и компонентные диаграммы (рис. 2, 3 б и 4).

Второй главный вывод заключается в том, что петрохимические черты всех петрографических разновидностей и двух крупнейших массивов щелочных гранитов совпадают с таковыми лебяжинских метавулканитов групп РГ-II, РГ-III и Г-IV. На вариационных диаграммах фигуративные точки средних составов этих плутонических пород ложатся в целом на тренды эволюции лебяжинских метавулканитов этих трех групп (рис. 2). Об этом же свидетельствует и расположение фигуративных точек западно-кейвских щелочных гранитов в области, единой для метавулканитов групп РГ-II, РГ-III и Г- $I V$ на диаграмме F1-F2 (рис. 5 б). 
Таким образом, проведенное на бо́льшем петрохимическом материале исследование подтвердило вывод о генетической связи лебяжинских кислых метавулканитов и щелочных гранитов, сделанный в работе (Balagansky et al., 2021). В этой же работе в метатрахириолите был описан бадделеит, сохранившийся в виде реликтов внутри кристалла циркона с возрастом $2678 \pm 7$ млн. лет. Петрографические, минералогические, петрохимические и геохимические данные указывают на отсутствие какой-либо метасоматической переработки этого метавулканита. Присутствие реликтов бадделеита в цирконе свидетельствует о генетической связи лебяжинских кислых метавулканитов с кейвскими габбро-анортозитами, которые внедрялись вместе со щелочными гранитами 2.67-2.66 млрд. лет назад в анорогенных условиях (Митрофанов и др., 2000; Баянова, 2004; Ветрин, Родионов, 2009; Кудряшов и др., 2019). Бадделеит кристаллизуется только в основных, ультраосновных и щелочноультраосновных породах, а также в карбонатитах и может присутствовать в кислых породах только в виде включений в минералах, тем или иным способом попавших в кислый расплав и изолировавших его от этого расплава (Heaman, LeCheminant, 1993). В основных породах описаны единичные случаи образования позднемагматического бадделеита в виде кайм вокруг магматического ильменита и включений в нем (Bingen et al., 2001), а также метаморфического бадделеита (Rubatto, Scambelluri, 2003). Образование метасоматического бадделеита рассмотрено на примере замещения детритового циркона бадделеитом в срастании с рутилом и редким фосфатом флоренситом по трещинам и в виде кайм в рудопроявлении Ичетъю, расположенном в осадочных породах Среднего Тимана (Скублов и др., 2018). Кристаллизация микроагрегатов этих минералов связывается с воздействием на циркон щелочных флюидов с температурой не менее 500-600 ${ }^{\circ}$, привносивших редкие земли, Y, $\mathrm{Nb}$ и Тi. Условия образования бадделеита во всех этих случаях не применимы для объяснения нахождения включений бадделеита внутри циркона в лебяжинском метатрахириолите.

\section{Благодарности}

Автор выражает глубокую благодарность П.Б. Соколову за всесторонние консультации по использованию метода главных компонент, представлению полученных результатов и их интерпретации. Автор также признателен Т.В. Картушинской за помощь в подготовке вариационных диаграмм и Т.В. Каулиной за внимательное прочтение рукописи и сделанные замечания, позволившие сделать текст более понятным.

Работа выполнена в рамках темы НИР № 0226-2019-052.

\section{Литература}

1. Батиева И.Д. Петрология щелочных гранитоидов Кольского полуострова. Л. Изд-во: Наука. 1976.224 с.

2. Баянова Т.Б. Возраст реперных геологических комплексов Кольского региона и длительность процессов магматизма. М. Изд-во: Наука. 2004. 174 с.

3. Белолипецкий А.П., Гаскельберг В.Г., Гаскельберг Л.А., Антонюк Е.С., Ильин Ю.И. Геология и геохимия метаморфических комплексов раннего докембрия Кольского полуострова. Л. 1980. 238 с.

4. Ветрин В.Р., Родионов Н.В. Геология и геохронология неоархейского анорогенного магматизма Кейвской структуры, Кольский полуостров // Петрология. 2009. Т. 17. № 5. С. 578-600.

5. Ветрин В.Р. Каменский И.Л., Баянова Т.Б., Тиммерман М., Беляцкий Б.В., Левский Л.К., Балашов Ю.А. Меланократовые включения и петрогенезис щелочных гранитоидов Понойского массива (Кольский полуостров) // Геохимия. 1999. № 11. С. 1178-1190.

6. Геологическая карта Кольского региона (северо-восточная часть Балтийского щита). Масштаб 1:500000 Гл. ред. Ф.П. Митрофанов. Отв. ред. А.Т. Радченко и К. Гиллен. Авторы: Балаганский В.В., Басалаев А.А., Беляев О.А., Пожиленко В.И., Радченко А.Т., Радченко М.К. Апатиты. ГИ КНЦ РАН. 1996.

7. Козлов Н.Н., Сорохтин Н. О., Мартынов Е.В., Марчук Т.С. Геодинамика Кейвского домена: петрогеохимический аспект // Вестник КНЦ РАН. 2019. № 3 (11). С. 80-86.

8. Кудряшов Н.М., Балаганский В.В., Удоратина О.В., Мокрушин А.В., Кобл М.А. Время формирования габбро-анортозитов Ачинского комплекса: U-Pb (SHRIMP RG) изотопно-геохронологическое изучение циркона // Труды Ферсмановской научной сессии ГИ КНЦ РАН. 2019. № 16. С. 318-322. 
9. Минц М.В. Кольский микроконтинент // Глубинное строение, эволюция и полезные ископаемые раннедокембрийского фундамента Восточно-Европейской платформы: Интерпретация материалов по опорному профилю 1-ЕВ, профилям 4В и ТАТСЕЙС. М.: ГЕОКАРТ: ГЕОС. 2010. Т. 1. С. 71-95.

10. Минц М.В., Глазнев В.Н., Конилов А.Н., Кунина Н.М., Никитичев А.П., Раевский А.Б., Седых Ю.Н., Ступак В.М., Фонарев В.И. Ранний докембрий северо-востока Балтийского щита: палеогеодинамика, строение и эволюция континентальной коры // М. Изд-во: Научный мир. 1996. 287 с. (Тр. ГИН РАН. Вып. 503).

11. Митрофанов Ф.П., Зозуля Д.Р., Баянова Т.Б., Левкович Н.В. Древнейший в мире анорогенный щелочногранитный магматизм в Кейвской структуре Балтийского щита // Доклады АН. 2000. Т. 374 . № 2. С. 238-241.

12. Скублов С.Г., Красоткина А.О., Макеев А.Б., Галанкина О.Л., Мельник А.Е. Уникальная находка преобразования циркона в бадделеит (рудопроявление Ичетью, Средний Тиман) // Известия высших учебных заведений. Геология и разведка. 2018. № 1. С. 27-35. DOI: 10.32454/0016-7762-2018-1-27-35.

13. Радченко А.Т., Балаганский В.В., Виноградов А.Н., Голионко Г.Б., Петров В.П., Пожиленко В.И., Радченко М.К. Докембрийская тектоника северо-восточной части Балтийского щита (объяснительная записка к тектонической карте масштаба 1: 500 000). СПб. Изд-во: Наука. 1992. 112 с.

14. Радченко А.Т., Балаганский В.В., Басалаев А.А., Беляев О.А., Пожиленко В.И., Радченко М.К. Объяснительная записка к геологической карте северо-восточной карте Балтийского щита масштаба 1:500 000. Апатиты. Изд-во: КНЦ РАН. 1994. 96 с.

15. Рябчиков И.Д. Физико-химические условия процессов генерации и дифференциации кислых и средних магм // Магматические горные породы. Т. 4. М.: Наука. 1987. С. 348-358.

16. Юдин Б.А. Габбро-лабрадоритовая формация Кольского полуострова и ее металлогения. Л. Изд-во: Наука. 1980. $168 \mathrm{c}$.

17. Balagansky V.V. Myskova T.A., Lvov P.A., Larionov A.N., Gorbunov I.A. Neoarchean A-type acid metavolcanics in the Keivy Terrane, northeastern Fennoscandian Shield: geochemistry, age, and origin // Lithos. 2020. V. 380-381. 105899. DOI: 10.1016/j.lithos.2020.105899.

18. Bingen B., Austrheim H., Whitehouse M. Ilmenite as a source for zirconium during high-grade metamorphism? Textural evidence from the Caledonides of Western Norway and implications for zircon geochronology // Journal of Petrology. 2001. V. 42. № 2. P. 355-375.

19. Heaman L.M., LeCheminant A.N. Paragenesis and U-Pb systematics of baddeleyite $\left(\mathrm{ZrO}_{2}\right) / /$ Chemical Geology. 1993. V. 110. P. 95-126.

20. Jolliffe I.T. Principal component analysis. New York, etc.: Springer-Verlag. 2002. 487 p. DOI: 10.1007/b98835.

21. Mikhailova J.A., Pakhomovsky Ya.A., Ivanyuk G.Yu., Bazai A.V., Yakovenchuk V.N., Elizarova I.R., Kalashnikov A.O. REE mineralogy and geochemistry of the Western Keivy peralkaline granite massif, Kola Peninsula, Russia // Ore Geology Reviews. 2017. V. 82. P. 181-197. DOI: 10.1016/j.oregeorev.2016.11.006

22. Nédélec A., Bouchez J.-L. Granites: Petrology, Structure, Geological Setting, and Metallogeny. Oxford: Oxford University Press. 2015. 348 p.

23. Rubatto D., Scambelluri M. U-Pb dating of magmatic zircon and metamorphic baddeleyite in the Ligurian eclogites (Voltri Massif, Western Alps) // Contributions to Mineralogy and Petrology. 2003. V. 146. P. $341-355$. DOI 10.1007/s00410-003-0502-X

24. Zozulya D.R., Eby G.N. The anorthosite-A-type peralkaline granite connection: a case study from the Keivy Terrane, Baltic Shield // Geological Association of Canada-Mineralogical Association of Canada, Joint Annual Meeting, Abstracts 33. Quebec: 2008. P. 190-191.

25. Zozulya D.R., Eby G.N. Geochemical constraints on the genetic relationship between A-type peralkaline granite and anorthosite from the Neoarchean Keivy alkaline province, NE Baltic Shield // Geochemistry of Magmatic Rocks. School «Geochemistry of alkaline rocks», Abstract Volume. Moscow: ONTI GEOKHI RAS Publishing. 2009. P. 180-182.

26. Zozulya D.R., Bayanova T.B., Eby G.N. Geology and Age of the Late Archean Keivy Alkaline Province, Northeastern Baltic Shield // The Journal of Geology. 2005. V. 113. P. 601-608. 